\title{
Respons Pertumbuhan Tanaman Kopi Robusta (Coffea robusta L.) Tercekam Aluminium di Lahan Reklamasi Bekas Tambang Batubara Bervegetasi Sengon (Periode El Nino)
}

\author{
Heru Rizka Santosa ${ }^{1}$, Cucu Suherman ${ }^{2}$ dan Santi Rosniawaty ${ }^{2}$ \\ ${ }^{1}$ PT. Kutai Energy, Loa Janan-Kutai Kartanegara, Kalimantan Timur \\ ${ }^{2}$ Staf Pengajar Program Studi Agronomi Fakultas Pertanian Universitas Padjadjaran \\ Jln Raya Bandung - Sumedang Km. 21 Jatinangor \\ Alamat korespondensi: rizkasantosa@yahoo.co.id
}

\begin{abstract}
Response on plant growth of Robusta coffee (Coffea robusta L.) to aluminum stress in reclamation of coal mines vegetated sengon (El Nino period)
\end{abstract}

Reclamation of coal mines commonly has low fertility rates with high aluminum saturation. Aluminum stress could be negative impact on plants that are not tolerant, can cause toxicity and inhibition of plant growth. This research in order to determine the effect of aluminum stress on plant growth of robusta coffee in reclamation of coal mines vegetated sengon. Stress aluminum effect on plant growth of Robusta coffee in reclamation is shown on parameter of plant height, stem diameter, leaf area, shoot dry weight, root length are lower than Robusta coffee plants in nurseries (control), and parameter of volume root, root dry weight are higher than the control. The content of aluminum (Al) in leaves of coffee plant in reclamation (117.7 ppm) is higher than control (26.1 ppm). Based on roots observation do not shown symptom of inhibition or toxicity of aluminum stress, and result of analysis of $\mathrm{Al}$ content in the roots is $25 \mathrm{ppm}$ belongs to category is low $(<60 \mathrm{ppm})$, then the Robusta coffee plant belongs to the category tolerant to aluminum stress in reclamation of coal mines vegetated sengon.

Keywords: Coffee, Stress, Aluminum (Al), Roots, Reclamation

\begin{abstract}
ABSTRAK
Lahan reklamasi bekas tambang batubara umumnya memiliki tingkat kesuburan rendah dengan kejenuhan aluminium tinggi. Cekaman aluminium berdampak negatif bagi tanaman yang tidak toleran dan dapat menimbulkan toksisitas sehingga mengakibatkan penghambatan pertumbuhan tanaman. Penelitian ini bertujuan untuk mengetahui pengaruh cekaman aluminium terhadap pertumbuhan tanaman kopi robusta pada lahan reklamasi bekas tambang batubara bervegetasi sengon. Hasil penelitian memperlihatkan cekaman aluminium di lahan reklamasi bekas tambang batubara bervegetasi sengon berpengaruh terhadap pertumbuhan tanaman kopi Robusta, yang ditunjukkan pada parameter tinggi tanaman, diameter batang, luas daun, bobot kering pupus, panjang akar yang lebih rendah dibandingkan tanaman kopi Robusta di nurseri (kontrol), dan parameter volume akar, bobot kering akar yang lebih tinggi dibandingkan kontrol. Kandungan aluminium (Al) di daun pada lahan reklamasi lebih tinggi (117,7 ppm) dibandingkan kontrol (26,1 ppm). Berdasarkan pengamatan akar pada tanaman kopi di lahan reklamasi, tidak terlihat gejala penghambatan atau toksisitas akibat cekaman $\mathrm{Al}$, dan hasil pengujian kandungan $\mathrm{Al}$ di akar adalah 25 ppm, termasuk kategori rendah $(<60 \mathrm{ppm})$, maka tanaman kopi Robusta termasuk kategori toleran terhadap cekaman aluminium yang terdapat di lahan reklamsi bekas tambang batubara bervegetasi sengon.
\end{abstract}

Kata kunci : Kopi, Cekaman, Aluminium (Al), Akar, Lahan reklamasi 


\section{PENDAHULUAN}

Kopi menjadi komoditi penting dalam perdagangan internasional sejak abad ke-19. Kebutuhan kopi di dunia setiap tahunnya terus meningkat. Data International Coffee Organization (ICO) tahun 2014 menunjukkan bahwa pertumbuhan konsumsi kopi dunia periode tahun 2008 - 2012 sebesar 6,9\%, dengan rata-rata pertumbuhan tiap tahunnya $1,7 \%$. Berdasarkan data Asosiasi Eksportir dan Industri Kopi Indonesia (AEKI) tahun 2014, konsumsi kopi di Indonesia pun mengalami pertumbuhan, tercatat dalam periode tahun 2008 - 2012 meningkat sebesar 9,1\% atau rata-rata pertumbuhan tiap tahunnya 2,3\%.

Peningkatan konsumsi (kebutuhan) kopi perlu diimbangi dengan peningkatan produksi, tetapi saat ini produksi kopi Indonesia cenderung menurun. Produksi kopi Indonesia yang menurun, satu di antaranya dipengaruhi luas areal perkebunan kopi yang menurun, pada tahun 2008 luas areal perkebunan kopi adalah 1.295 .110 ha dan tahun 2012 menjadi 1.235.289 ha, mengalami penurunan sebesar 4,62\%. Menyikapi hal tersebut maka Direktorat Jenderal Perkebunan Kementerian Pertanian melakukan program untuk meningkatkan produksi kopi nasional di antaranya dengan mempercepat perluasan areal tanam perkebunan kopi (Ditjenbun, 2014).

Provinsi Kalimantan Timur memiliki potensi besar dalam pengembangan perkebunan kopi. Provinsi Kalimantan Timur memiliki lahan yang sangat luas untuk mendukung program perluasan areal tanam kopi, salah satunya adalah tersedianya lahan-lahan bekas tambang batubara yang belum termanfaatkan dengan optimal untuk kegiatan pertanian atau perkebunan yang bernilai ekonomis. Lahan reklamasi bekas tambang batubara yang telah direvegetasi dengan tanaman sengon atau tanaman fast growing lainnya perlu ditanami tanaman sisipan berupa tanaman lokal atau tanaman perkebunan yang biasa dibudidayakan di area tersebut sebagai bagian dari kriteria penilaian keberhasilan untuk pencairan jaminan reklamasi (Dirjen Minerba, 2012). Tanaman kopi dalam budidayanya memerlukan naungan dan sengon sebagai tanaman fast growing dapat menjadi tanaman penaung sehingga konsep agroforestri dalam revegetasi lahan bekas tambang dapat diterapkan. Hal tersebut sejalan dengan program Bappenas (2011) mengenai Kebijakan Nasional Mitigasi Perubahan Iklim yaitu pemanfaatan lahan tidur, terlantar, terganggu dan terdegradasi untuk menghindari deforestasi dan mengurangi degradasi lahan.

Kendala utama pada lahan reklamasi bekas tambang batubara adalah tingkat kesuburannya yang rendah, di antaranya ketersediaan hara seperti $\mathrm{P}, \mathrm{Ca}$, $\mathrm{Mg}$ sangat terbatas. Hal ini dikarenakan lahan reklamasi merupakan timbunan tanah hasil galian batubara yang dominan berupa lapisan sub soil dan bahan induk sehingga kondisi lahan reklamasi memiliki $\mathrm{pH}$ yang rendah (masam) serta kejenuhan aluminium (Al) tinggi akibat terjadi degradasi kimia tanah (Rahmah \& Sidik, 2006). Masalah lain pada lahan reklamasi adalah kemampuan tanaman untuk menyerap hara juga dibatasi oleh kandungan $\mathrm{Al}$ yang tinggi. Cekaman aluminium terutama dalam bentuk $\mathrm{Al}^{3+}$ yang sangat beracun bagi tanaman dapat menimbulkan toksisitas bagi tanaman dan menghambat pertumbuhannya (Kartika dkk., 2012).

Cekaman (stress) adalah suatu kondisi yang memberikan tekanan pada tanaman dan mengakibatkan respons tanaman terhadap faktor lingkungan tertentu berbeda daripada respons optimumnya pada kondisi normal, dan setiap tanaman memiliki faktor pembatas serta daya toleransi terhadap lingkungan (Purwadi, 2011). Menurut Utama dkk. (2004), walaupun keberadaan Al yang tinggi dapat menimbulkan cekaman bagi tanaman tetapi sampai ambang tertentu pengaruh $\mathrm{Al}$ dapat ditoleransi oleh tanaman yang toleran. Tanaman kopi dapat tumbuh di berbagai kondisi tanah, dari yang sangat masam $(\mathrm{pH}<4)$ sampai tanah alkalin $(\mathrm{pH}>8)$, dan untuk kopi Robusta umumnya dapat tumbuh pada lahan dengan $\mathrm{pH}>$ 4,5 (Forestier, 1969 dalam Wilson \& Clifford, 1985). Hal tersebut menunjukkan bahwa tanaman kopi Robusta relatif toleran ditanam di lahan masam. Umumnya lahan masam memiliki tingkat kejenuhan aluminium tinggi, tetapi pengaruh cekaman aluminium belum diketahui lebih mendalam terhadap parameter pertumbuhan tanaman kopi.

Pengaruh cekaman aluminium pada tanaman yang tidak toleran dapat menyebabkan perubahan pada bentuk (morfologis) akar, yaitu akar menjadi melengkung, membengkak (gemuk), retak-retak dan ujung akar menjadi kaku (Vardar \& Meral, 2007). Kerusakan pada akar dapat menyebabkan defisiensi hara seperti P, Ca dan Mg sehingga mengakibatkan daun muda menggulung / keriting, mengurangi pembukaan stomata, penurunan aktivitas fotosintesis, penurunan kandungan klorofil (klorosis) dan nekrosis daun (Vitorello et al., 2005). Menurut Wilson \& Clifford (1985), gejala toksisitas pada bagian tajuk (pupus) akibat cekaman 
aluminium pada tanaman kopi dicirikan dengan terjadinya nekrosis dan keriting pada daun muda, serta klorosis diantara urat lateral daun, sedangkan pada daun tua terdapat bercak nekrosis yang dimulai dari pucuk kemudian menjalar ke tengah.

Kajian mengenai pengaruh cekaman aluminium ( $\mathrm{Al}$ ) pada tanaman kopi telah dilakukan oleh Martinez \& Monnerat, (1991) dalam Marcos et al. (2007). Hasilnya menunjukkan perlakuan dosis Al lebih dari $4 \mathrm{mg} / \mathrm{l}$ dalam larutan nutrisi selama empat bulan menyebabkan pertumbuhan akar lateral dan rambut akar terhambat, penurunan tinggi, panjang ruas dan luas daun, serta perlakuan pada dosis $8 \mathrm{mg} / \mathrm{l}$ atau $16 \mathrm{mg} / \mathrm{l} \mathrm{Al}$ menyebabkan penurunan bobot kering akar, bobot kering pupus dan rasio (nisbah) pupus akar. Hasil uji kandungan Al pada tanaman kopi yang mengalami toksisitas $\mathrm{Al}$ menunjukkan bila Al lebih banyak terakumulasi pada akar dan sebagian kecil ditranslokasi ke bagian pupus.

Terdapat dua cara tanaman mengatasi cekaman Al, yaitu dengan mekanisme eksternal dan mekanisme internal. Mekanisme eksternal yaitu tanaman mencegah $\mathrm{Al}$ masuk ke dalam jaringan antara lain dengan mengeksudasi asam organik dari akar yang dapat berikatan dengan $\mathrm{Al}$ di rizosfer. Asam organik tersebut dapat membentuk khelat dengan Al di rizosfer sehingga tidak bersifat racun bagi tanaman. Mekanisme internal yaitu tanaman dapat mentolerir kehadiran Al di dalam jaringan dengan cara menghasilkan asam organik atau ligan organik yang dapat berikatan dengan Al sehingga terbentuk khelat yang tidak bersifat racun, atau mengakumulasinya di vakuola pada daun (Vardar \& Meral, 2007). Tujuan penelitian ini adalah untuk mengetahui peluang penanaman kopi robusta (Coffea robusta L.) di lahan reklamasi bekas tambang batubara dengan mengkaji respons pertumbuhan tanaman kopi Robusta terhadap cekaman aluminium (Al).

\section{BAHAN DAN METODE}

Penelitian dilakukan di lahan reklamasi PT. Kutai Energi, Desa Tani Harapan, Kec. Loa Janan, Kab. Kutai Kartanegara dengan ketinggian tempat < $100 \mathrm{~m}$ dpl, ordo tanah Ultisol dan memiliki kejenuhan Al sangat tinggi (59\%), serta tipe iklim A (sangat basah) menurut klasifikasi Schmidt \& Fergusson (1951). Penelitian berlangsung pada bulan April 2015 sampai dengan Oktober 2015. Penelitian ini membandingkan respons pertumbuhan tanaman kopi robusta yang ditanam di lahah reklamasi bekas tambang batubara dengan tanaman kopi yang dipelihara dalam nurseri (kontrol). Jumlah sampel tanaman kopi masing-masing perlakuan yang diamati sejumlah 20 tanaman, jadi jumlah total tanaman sebanyak 40 tanaman. Parameter yang diamati adalah tinggi tanaman, diameter batang, panjang akar, volume akar, bobot kering pupus, bobot kering akar, nisbah pupus akar, kandungan $\mathrm{Al}$ di akar dan daun. Data yang diperoleh dianalisa dengan menggunakan uji $\mathrm{T}$.

\section{HASIL DAN PEMBAHASAN}

Hasil analisis staitistik Uji $\mathrm{T}$ menunjukkan bahwa semua parameter pengamatan memiliki nilai t hitung rata-rata lebih besar dari t tabel, maka Ho ditolak, artinya bahwa ada perbedaan antara nilai pengamatan rata-rata tanaman kopi yang berada di lahan reklamasi dengan yang berada di nurseri (kontrol). Parameter yang berbeda itu mencakup tinggi tanaman, diameter batang, luas daun, panjang akar, volume akar, bobot kering akar, bobot kering pupus, nisbah pupus akar dan nisbah akar pupus, datanya ditunjukkan pada Tabel 1.

Tabel 1. Uji T respons pertumbuhan tanaman kopi Robusta tercekam aluminium pada 6 bulan setelah tanam (BST).

\begin{tabular}{lcccc}
\hline \multirow{2}{*}{ Parameter } & \multicolumn{2}{c}{ Nilai pengamatan (rata-rata) } & \multirow{2}{*}{ T hitung } & T tabel \\
\cline { 2 - 4 } & Lahan Reklamasi & Nurseri (kontrol) & & 1,68 \\
\hline Tinggi tanaman $(\mathrm{cm})$ & 83,90 & $102,6^{*}$ & 4,12 & \\
Diameter batang $(\mathrm{mm})$ & 7,51 & $9,21^{*}$ & 2,70 & \\
Luas daun ke 3(cm $\left.{ }^{2}\right)$ & 94,64 & $130,66^{*}$ & 3,35 & \\
Panjang akar $(\mathrm{cm})$ & 26,55 & $39,10^{*}$ & 5,49 & \\
Volume akar $(\mathrm{ml})$ & $27,25^{*}$ & 21,70 & 2,30 \\
Bobot kering akar $(\mathrm{g})$ & $23,02^{*}$ & 16,22 & 3,97 \\
Bobot kering pupus $(\mathrm{g})$ & 39,38 & $53,59^{*}$ & 2,46 \\
Nisbah pupus akar & 1,77 & $3,13^{*}$ & 6,25 \\
\hline
\end{tabular}

Keterangan: Nilai rata-rata yang ditandai dengan tanda * pada baris yang sama menunjukkan hasil berbeda nyata berdasarkan uji T pada taraf $5 \%$. 
Respons akar (bentuk akar, panjang akar, volume akar, bobot kering akar) terhadap cekaman aluminium

Menurut Vardar \& Meral (2007), pengaruh akibat cekaman aluminium pada tanaman yang tidak toleran terlihat dari perubahan pada bentuk akarnya yaitu akar melengkung, membengkak (gemuk), retak-retak dan ujung akar menjadi kaku. Mengamati morfologis akar tanaman kopi di lahan reklamasi yang ditunjukkan pada Gambar 1, pertumbuhan dan bentuk akar relatif normal dan tidak tampak perubahan bentuk akar seperti yang disebutkan di atas.
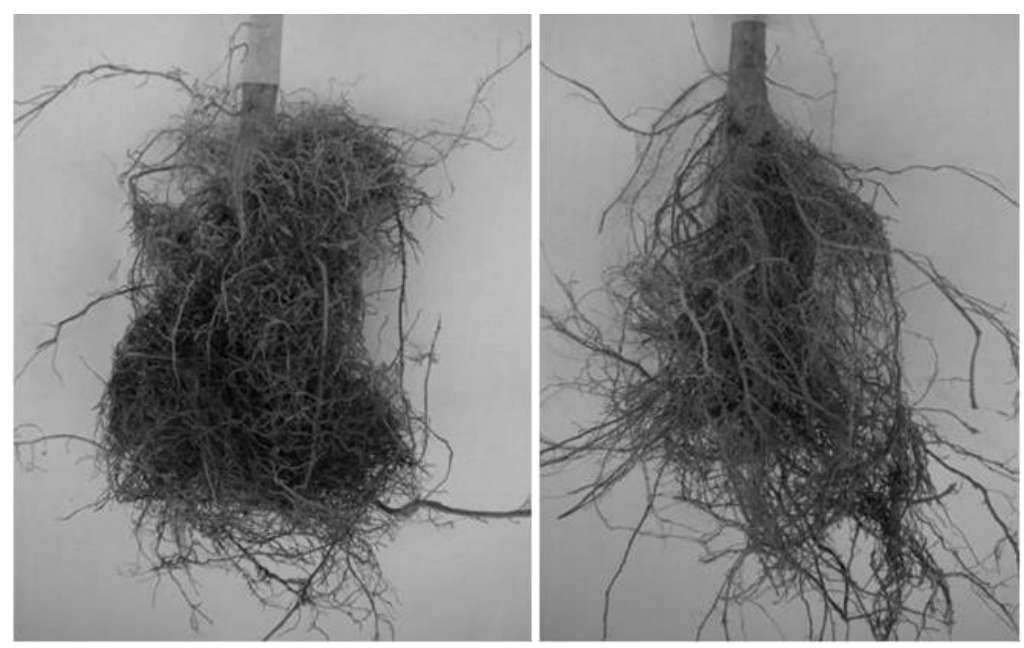

a. Akar tanaman kopi lahan reklamasi
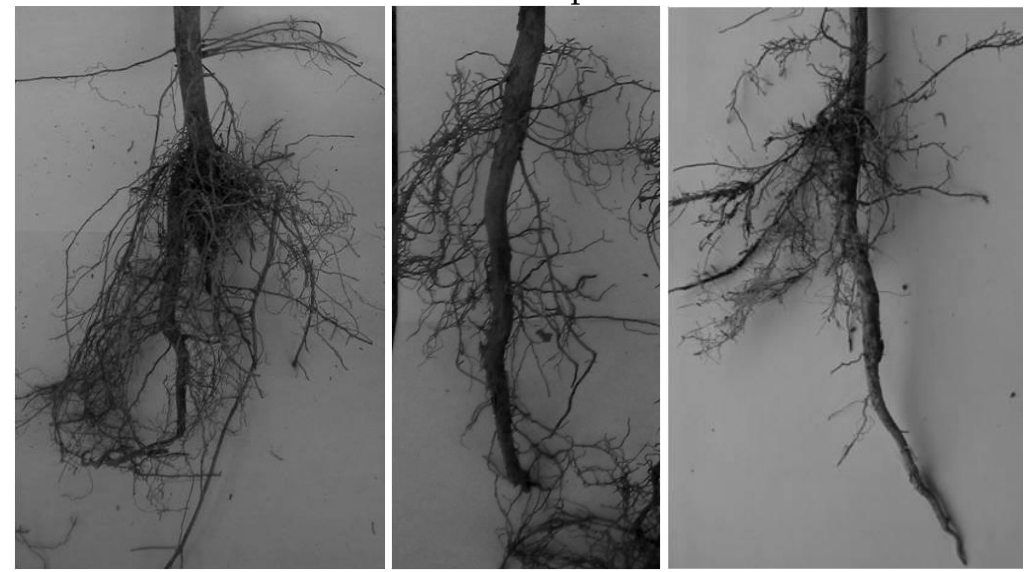

b. Akar tanaman kopi nurseri

Gambar 1. Morfologis akar tanaman kopi lahan reklamasi (a) dan nurseri (b).

Data hasil penelitian pada Tabel 1 menunjukkan bahwa tanaman kopi di lahan reklamasi memiliki panjang akar lebih rendah dibandingkan tanaman kopi di nurseri, tetapi untuk parameter volume akar dan bobot kering akar nilainya lebih tinggi dibandingkan akar tanaman kopi di nurseri yang tidak mengalami cekaman aluminium. Toleransi tanaman kopi pada cekaman aluminium telah diteliti oleh Braccini et al. (1998) dalam Marcos et al. (2007), hasilnya menunjukkan tanaman kopi yang tidak toleran terhadap cekaman aluminium dapat mengakibatkan penurunan panjang akar, luas permukaan akar (volume akar) dan berkurangnya bobot kering akar.

Respons pupus (tinggi tanaman, diameter batang, luas daun, bobot kering pupus) terhadap cekaman aluminium

Respons pada bagian pupus akibat cekaman aluminium sulit untuk diidentifikasi, gejala yang tampak pada bagian pupus umumnya merupakan dampak dari kerusakan pada akar yang menyebabkan defisiensi hara dan mengakibatkan daun muda menggulung/keriting, klorosis di antara urat lateral daun, pada daun tua terdapat bercak 
nekrosis yang dimulai dari pucuk kemudian menjalar ke tengah, penurunan kandungan klorofil (Wilson, 1985; Vitorello et al., 2005). Menurut Makarim (2006) toksisitas Al dalam beberapa kasus
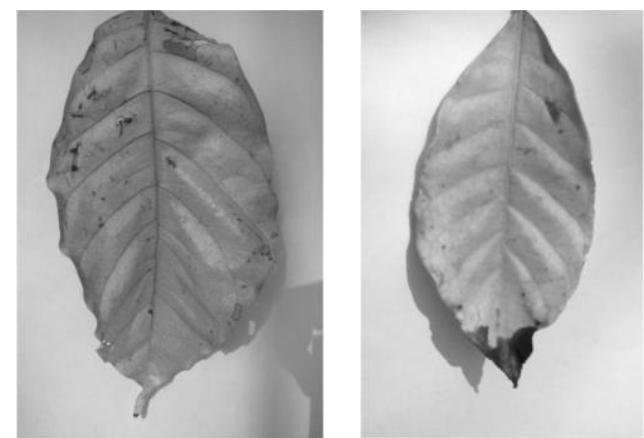

a. Daun tanaman kopi lahan reklamasi dapat memicu defisiensi kalsium (Ca) atau mengurangi masalah transportasi $\mathrm{Ca}$ sehingga menyebabkan keriting atau menggulungnya daun muda dan matinya titik tumbuh pada pucuk daun.
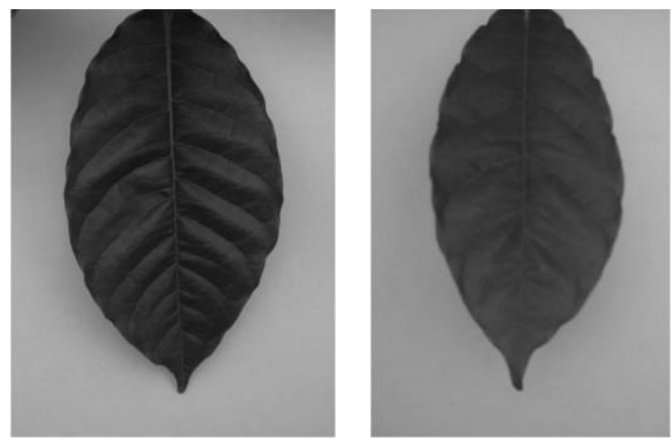

b. Daun tanaman kopi nurseri

Gambar 2. Perbedaan kondisi daun kopi lahan reklamasi (a) dan nurseri (b).

Pengamatan pada daun tanaman kopi di lahan reklamasi (Gambar 2.) tidak terlihat gejala daun muda menggulung/keriting, klorosis di antara urat lateral daun. Gejala yang mencolok terlihat adalah warna daun menguning yang mengindikasikan rendahnya kandungan klorofil (defisiensi $\mathrm{N}$ ) dan nekrosis di ujung daun yang mengindikasikan defisiensi $\mathrm{Mg}$.

Berdasarkan data hasil penelitian pada Tabel 1, menunjukkan bahwa parameter tinggi tanaman, diameter batang, luas daun, bobot kering pupus pada tanaman kopi di lahan reklamasi memiliki nilai yang lebih rendah dibandingkan tanaman kopi di nurseri (kontrol). Hal ini menimbulkan suatu dugaan apakah hal tersebut merupakan respons akibat cekaman aluminium atau ada faktor lingkungan lain yang mempengaruhi. Menurut Zulman, (2008) cekaman Al yang menyebabkan penghambatan pertumbuhan akar akan mengakibatkan terhambatnya atau berkurangnya serapan hara seperti P, K, Ca dan Mg sehingga dapat menurunkan pertumbuhan pada bagian pupus seperti tinggi tanaman, diameter batang, luas daun. Sebagaimana diketahui pengamatan pada akar tanaman kopi di lahan reklamasi tidak terjadi penghambatan, bahkan pertumbuhannya lebih baik dibandingkan akar tanaman kopi di nurseri.

Sistem akar yang ideal asumsinya akan menunjang pertumbuhan optimal tanaman, tetapi parameter pertumbuhan seperti tinggi tanaman, diameter batang, luas daun, bobot kering pupus pada tanaman kopi di lahan reklamasi menunjukkan hal yang tidak sejalan, yaitu nilainya lebih rendah dibandingkan tanaman kopi di nurseri. Keadaan ini menimbulkan suatu dugaan bila faktor kesuburan tanah atau ketersediaan hara di tempat tumbuh tanaman menjadi faktor yang berpengaruh.

Membandingkan kondisi kesuburan tanah berdasarkan analisis tanah yang ditunjukkan pada Tabel 2, terlihat bila tanah lahan reklamasi dan tanah nurseri memiliki tingkat ketersediaan hara yang berbeda. Tanah di lahan reklamasi memiliki kandungan hara $\mathrm{N}, \mathrm{P}, \mathrm{K}, \mathrm{Ca}$ dan $\mathrm{Mg}$ lebih rendah, sehingga dalam menghadapi kondisi tersebut akar perlu lebih berkembang untuk mencari hara yang dibutuhkan tanaman. Menurut Harjadi \& Yahya (1988), kemampuan akar untuk menyebarkan atau memperluas sistem perakaran adalah untuk memperoleh suplai hara.

Tabel 2. Kandungan hara N, P, K, Ca, Mg di tanah reklamasi dan nursery.

\begin{tabular}{lccccc}
\hline & $\mathrm{N}(\%)$ & $\mathrm{P}(\mathrm{ppm})$ & $\mathrm{K}(\mathrm{ppm})$ & $\mathrm{Ca}(\mathrm{meq} 100 / \mathrm{g})$ & $\mathrm{Mg}(\mathrm{meq} 100 / \mathrm{g})$ \\
\hline Tanah nurseri (kontrol) & $0,16 \mathrm{R}$ & $309,5 \mathrm{ST}$ & $106,5 \mathrm{ST}$ & $2,62 \mathrm{R}$ & $1,38 \mathrm{~S}$ \\
Tanah reklamasi & $0,10 \mathrm{R}$ & $13,4 \mathrm{R}$ & $72,6 \mathrm{ST}$ & $0,53 \mathrm{SR}$ & $0,32 \mathrm{SR}$ \\
\hline
\end{tabular}

Sumber : Laboratorium Ilmu Tanah Universitas Mulawarman, Samarinda, Kaltim, 2015.

Keterangan $: \mathrm{SR}=$ sangat rendah, $\mathrm{R}=$ rendah, $\mathrm{S}=$ sedang, $\mathrm{T}=$ tinggi, $\mathrm{ST}$ = sangat tinggi

Respons tanaman di lahan reklamasi pertumbuhan pada bagian pupus (tajuk). Ada pertumbuhan akarnya lebih dominan dibandingkan kemungkinan lain selain faktor kesuburan tanah 
yang mengakibatkan hal tersebut. Hal lain yang membedakan respons tanaman di lahan reklamasi dengan di nurseri selain faktor perbedaan kesuburan tanah adalah perbedaan perlakuan penyiraman. Tanaman di lahan reklamasi, kebutuhan airnya tergantung dari hujan, sedangkan tanaman kopi di nurseri dilakukan penyiraman secara rutin setiap dua hari sekali.

Berdasarkan data curah hujan (Tabel 3), terlihat bila tanaman kopi di lahan reklamasi mengalami bulan kering yang cukup panjang selama empat bulan yaitu dari bulan Juli - Oktober 2015 sebagai dampak dari fenomena El Nino. Keadaan tersebut akan menimbulkan cekaman bagi tanaman, khususnya cekaman air (kekeringan). Kondisi cekaman kekeringan tersebut kemungkinan besar berpengaruh terhadap respons pertumbuhan tanaman di lahan reklamasi.

Tabel 3. Curah hujan rata-rata periode Januari - Desember 2015.

\begin{tabular}{lccccccccccccc}
\hline Bulan & Jan & Feb & Mar & Apr & Mei & Jun & Jul & Ags & Sep & Okt & Nop & Des & Total \\
\hline $\begin{array}{l}\text { Curah } \\
\begin{array}{l}\text { Hujan } \\
(\mathrm{mm})\end{array}\end{array}$ & 263 & 236 & 273 & 357 & 124 & 154 & 25 & 29 & 0 & 54 & 129 & 119 & 1.763 \\
\hline
\end{tabular}

Sumber : BMKG Temindung, Samarinda, 2016.

Menurut Budiasih (2009), respons morfologi yang penting dalam proses adaptasi tanaman terhadap kekurangan air adalah peningkatan panjang dan volume akar. Sistem akar yang pertumbuhannya pesat dapat memaksimumkan pemaparan air tanah (Campbell et al., 2003). Tanaman dengan volume akar yang besar akan mampu mengabsorbsi air lebih banyak sehingga mampu bertahan pada kondisi kekurangan air (Palupi \& Dedywiryanto, 2008).

Menurut Chaniago et al. (2005), kondisi cekaman kekeringan pada stadia vegetatif dapat menurunkan tinggi tanaman dan luas daun atau laju pelebaran daun. Jordan et al., (1983) juga menyatakan bahwa tanaman akan menghasilkan sedikit pertumbuhan vegetatif dan pengurangan luas daun untuk mengurangi kehilangan air. Hal ini memperkuat dugaan bahwa faktor cekaman kekeringan juga turut berpengaruh terhadap penurunan pertumbuhan seperti tinggi tanaman, diameter batang dan luas daun.

Hasil penelitian menunjukkan bobot kering pupus (biomassa) tanaman kopi di lahan reklamasi lebih rendah dibandingkan tanaman kopi di nurseri. Menurut Zulman (2008), paparan jangka panjang Al yang menyebabkan kekurangan $\mathrm{P}, \mathrm{K}, \mathrm{Ca}, \mathrm{Mg}$ dan hara lainnya dapat mengakibatkan berkurangnya biomassa tanaman. Menurut Solichatun et al. (2005), berkurangnya biomassa tanaman pada saat kekurangan air disebabkan oleh penurunan aktivitas fotosintesis dan penyusutan luas daun. Penurunan akumulasi biomassa akibat kekurangan air untuk setiap jenis tanaman bervariasi tergantung pada respons masing-masing jenis tanaman terhadap kekurangan air.

\section{Nisbah pupus akar}

Nilai nisbah pupus akar hasil penelitian menunjukkan bila pertumbuhan akar lebih dominan dibandingkan tajuknya pada tanaman kopi di lahan reklamasi. Respons tanaman yang mengalami kekurangan air dapat melakukan perubahan di tingkat selular dan molekular yang ditunjukkan dengan penurunan laju pertumbuhan, berkurangnya luas daun dan peningkatan pertumbuhan akar dibandingkan pertumbuhan tajuk (pupus). Nisbah pupus akar merupakan perbandingan antara pertumbuhan (bobot kering) pupus dan pertumbuhan (bobot kering) akar. Nilai nisbah pupus akar yang rendah berkaitan dengan kemampuan absorbsi air oleh tanaman yang meningkat sebagai salah satu mekanisme untuk mempertahankan potensial air yang tetap tinggi pada saat tanaman mengalami kekurangan air (Palupi \& Dedywiryanto, 2008).

Respons tanaman pada saat kekurangan air akan menyebabkan pertumbuhan sistem perakaran meningkat, sedangkan pertumbuhan tajuk menurun. Tanaman yang lebih mementingkan pertumbuhan akar daripada pertumbuhan tajuk, akan memiliki kemampuan yang lebih baik untuk bertahan pada kondisi kekurangan air. Jadi nilai nisbah pupus akar pada tanaman kopi di lahan reklamasi yang lebih rendah dari tanaman kopi di nurseri kemungkinan merupakan suatu respons menghadapi cekaman kekeringan. 
Respons tanaman kopi terhadap cekaman kekeringan air dengan meningkatkan pertumbuhan pada bagian akar menjadi suatu indikasi bila tanaman kopi memiliki kemampuan toleransi terhadap cekaman aluminium. Tanpa kemampuan toleransi terhadap cekaman aluminium maka tanaman kopi di lahan reklamasi tidak dapat bertahan hidup dikarenakan akar tidak dapat tumbuh dan berkembang untuk menyerap hara atau air yang dibutuhkan.

\section{Kandungan Al di akar dan daun}

Keberadaan Al di akar dan daun dapat menjelaskan mekanisme tanaman dalam menghadapi cekaman Al. Aluminium diserap oleh akar melalui ujung akar dan tudung akar. Menurut Rout et al. (2001), Al terserap akar kemudian melewati epidermis dan korteks, sebagian lainnya $\mathrm{Al}$ terserap akar kemudian melalui dinding sel (apoplas) serta sebagian lainnya melalui sitoplasma (simplas). Kandungan Al pada akar dan daun ditunjukkan pada Tabel 3.

Tabel 3. Kandungan aluminium (Al) di akar dan daun kopi Robusta.

\begin{tabular}{lcc}
\hline \multirow{2}{*}{ Perlakuan } & \multicolumn{2}{c}{ Kandungan Aluminium $(\mathrm{Al})(\mathrm{ppm})$} \\
\cline { 2 - 3 } & Akar & Daun \\
\hline Reklamasi & 25,0 & 117,7 \\
Nurseri (Kontrol) & 11,5 & 26,1 \\
\hline
\end{tabular}

Sumber : Hasil Uji Laboratorium Ilmu Tanah Universitas Mulawarman, Samarinda, Kaltim, 2016.

Kandungan Al di akar pada tanaman kopi di lahan reklamasi yaitu $25 \mathrm{ppm}$, masih dibawah ambang batasnya yaitu $<60 \mathrm{ppm}$ (Wilson \& Clifford, 1985). Berdasarkan hasil penelitian Martinez \& Monnerat (1991) dalam Marcos et al. (2007) menunjukkan bahwa tanaman kopi yang mengalami toksisitas Al maka Al lebih banyak terakumulasi pada akar dan sebagian kecil ditranslokasi ke bagian pupus. Tanaman dapat mentolerir kehadiran $\mathrm{Al}$ di dalam jaringan dengan cara menghasilkan asam organik atau ligan organik yang dapat berikatan dengan $\mathrm{Al}$ sehingga terbentuk khelat yang tidak bersifat racun, atau dengan mengakumulasi (mengkarantina) Al dalam kompartemen vakuola (Taylor, 1988). Hal tersebut menjadi indikator bila akar kopi tidak mengalami toksisitas Al akibat cekaman $\mathrm{Al}$, sehingga hal ini menjelaskan mengapa pertumbuhan akar kopi tidak mengalami perhambatan.

Kandungan $\mathrm{Al}$ di daun pada tanaman kopi di lahan reklamasi memiliki nilai lebih besar dibandingkan dengan daun tanaman kopi yang berada di nurseri. Berdasarkan kriteria College of Tropical Agriculture University of Hawaii (2005) ambang batas $\mathrm{Al}$ pada daun kopi yaitu $<120$ ppm, dan Al di daun pada lahan reklamasi hampir mendekati (117,7 ppm). Hal ini menjelaskan bahwa mekanisme tanaman kopi dalam mentolerir keberadaan (cekaman) Al yaitu melalui mekanisme internal yaitu mentolerir keberadaan $\mathrm{Al}$ di dalam jaringan kemudian mentransportasi dan mengakumulasinya pada kompartemen vakuola daun.

\section{SIMPULAN}

Cekaman aluminium berpengaruh terhadap pertumbuhan tanaman kopi robusta di lahan reklamasi yang ditunjukkan pada parameter tinggi tanaman, diameter batang, luas daun, bobot kering pupus, panjang akar yang lebih rendah dibandingkan tanaman kopi robusta di nurseri (kontrol), dan parameter volume akar, bobot kering akar yang lebih tinggi dibandingkan kontrol. Kandungan aluminium (Al) di daun pada tanaman kopi di lahan reklamasi lebih tinggi (117,7 ppm) dibandingkan kontrol (26,1 ppm).

Berdasarkan pengamatan akar menunjukkan tidak terlihat gejala penghambatan atau toksisitas akibat cekaman $\mathrm{Al}$, dan hasil pengujian kandungan $\mathrm{Al}$ di akar di akar adalah 25 ppm, termasuk kategori rendah (<60 ppm), maka tanaman kopi robusta dapat dikategorikan toleran terhadap cekaman aluminium yang terdapat di lahan reklamasi bekas tambang batubara bervegetasi sengon.

\section{DAFTAR PUSTAKA}

Asosiasi Eksportir dan Industri Kopi Indonesia (AEKI). 2014. Konsumsi kopi domestik. Available online at: http://www.aekiaice.org (diakses 27 April 2015).

Bappenas. 2011. Kebijakan nasional mitigasi dan adaptasi perubahan iklim. Tersedia online pada: http://www.bappenas.go.id (diakses 11 Februari 2014). 
Badan Pusat Statistik (BPS). 2014. Statistik perkebunan indonesia. Tersedia online pada: http://www. bps.go.id. (diakses 19 Maret 2014).

Budiasih. 2009. Respon tanaman padi gogo terhadap cekaman kekeringan. Ganec Swara Edisi Khusus 3(3): 22-27.

Campbell, NA, JB Reece, dan LG Mitchell. 2003. Biologi Jilid I. Terjemahan Wulandari dan Darmining Tyas. Penerbit Erlangga. Jakarta.

Chaniago, I, A Taji, and R Jessop. Assesment of allelophatic interaction soybean and Amaranthus powellii and Cyperus rotundus using in vitro system. Tersedia online pada: http://www.blackwell.com (diakses 11 April 2016).

College of Tropical Agriculture. 2005. Coffee growing basics: fertilizer, disease, insects. University of Hawai. Manoa.

Dirjen Minerba. 2012. Tata cara pencairan jaminan reklamasi. Kementrian Energi Sumber Daya Mineral.

Ditjenbun. 2014. Percepatan perluasan dan peremajaan tanaman kopi. Tersedia online pada : http://www.ditjenbun.pertanian.go.id (diakses 19 Maret 2014).

Harjadi, SS dan A Yahya. 1988. Fisiologi stress lingkungan. IPB, Bogor

International Coffee Organization (ICO). 2014. Statistics world coffee compsution. Available online at http://www.ico.org (diakses 11 Februari 2015).

Jordan, WR, WA Dugas Jr, and PJ Shouse. 1983. Strategies for crop improvement for drought-prone regions. Agricultural Water Management 7 (1-3): 281-299.

Kartika, E, Lizawati dan Hamzah. 2012. Isolasi, identifikasi dan pemurnian cendawan mikoriza arbuskulas (cma) dari tanah bekas tambang batubara. Bioplante 1 (4): 1-11.

Makarim, AK. 2006. Cekaman abiotik utama dalam peningkatan produktivitas tanaman. seminar nasional pemanfaatan bioteknologi untuk mengatasi cekaman abiotik pada tanaman. Bogor 22 September 2005. Balai Besar Penelitian dan Pengembangan Bioteknologi dan Sumberdaya Genetik Pertanian. Bogor. 14 hlm.
Marcos, SM, HEP Martinez, JC Neves, PTG Guimaraes, and AW Pedrosa. 2007. Coffeetree lime response in soil with high aluminium saturation. Coffee Science, Lavras 2 (2): 112-122.

Palupi, ER dan Y Dedywiryanto. 2008. Kajian karakter toleransi cekaman kekeringan pada empat genotipe bibit kelapa sawit (Elaeis guineensis). Bul. Agron (36) (1) 24 -32.

Purwadi, E. 2011. Pengujian ketahanan benih terhadap cekaman lingkungan. Tersedia online pada: http://www.masbied.com (diakses 11 April 2016).

Rout GR, S Samantaray and P Das. 2001. Aluminium toxicity in plants: a review. Agronomie. 21: 3-21.

Solichatun, E Anggarwulan, dan W Mudyantini. 2005. Pengaruh ketersediaan air terhadap pertumbuhan dan kandungan bahan aktif saponin tanaman ginseng Jawa (Talinum paniculatum Gaertn.). Jurnal Biofarmasi 3 (2): $\quad 47-51$.

Taylor, GJ. 1988. The physiology of aluminum phytotoxicity. In Metal Ions in Biological System. Vol 24. Aluminum and Its Role in Biology (Sigel, $\mathrm{H}$ and A Sigel). Marcel Dekker. New York.

Utama, MZH, YM Zen, dan W Haryoko. 2004. Mekanisme fisiologi toleransi terhadap cekaman aluminium pada spesies legum penutup tanah. Jurnal Stigma XII (2) 186 191.

Vardar, F, and U Meral. 2007. Aluminium toxicity and resistance in higher plants. Advances in Molecular Biology (1): 1-12.

Vitorello, VA, FRC Capaldi, and VA Stefanuto. 2005. Recent advances in aluminium toxicity and resistance in higher plants. Braz J Plant Physiol. 17: 129-143.

Wilson, KC, and MN Clifford. 1985. Coffee, botany, biochemistry and production of beans and beverage. The AVI Publishing Company, Inc. Westport. Connecticut. USA.

Zulman, MHH. 2008. Mekanisme fisiologi toleransi cekaman aluminium spesies legum penutup tanah terhadap metabolisme nitrat $\left(\mathrm{NO}_{3}^{-}\right)$, amonium $\left(\mathrm{NH}_{4}^{+}\right)$, dan nitrit $\left(\mathrm{NO}_{2}^{-}\right)$. Bul. Agron. (36) (2) 176 - 180. 